9. Ordóñez N.G., Mackay B. Electron microscopy in tumor diagnosis: indications for its use in the immunohistochemical era. Human Pathology. 1998. V. 29(12): P. 1403-1411.

10. Eydenf B. Electron microscopy in the diagnosis of tumours. Current Diagnostic Pathology. 2002. V. 8(4). P. 216-224.

11. Schroeder J.A., Gelderblom H.R., Hauroeder B., Schmetz C., Milios J., Hofstaedtera F. Microwave-assisted tissue processing for sameday EM-diagnosis of potential bioterrorism and clinical samples. Micron. 2006. V. 37(6). P. 577-590.

DOI https://doi.org/10.30525/978-9934-26-111-4-30

\title{
ГЕНЕТИЧНА ДИФЕРЕНЦАЦІЯ МІДІЙ РОДУ MYTILUS ПІВНІЧНО-ЗАХІДНОЇ ЧАСТИНИ ЧОРНОГО МОРЯ
}

\author{
Чубик I. Ю. \\ аспірантка \\ Одеський національний університет імені I. I. Мечникова \\ Чеботар C. B. \\ доктор біологічних наук, професор, \\ завідувач кафедри генетики та молекулярної біології \\ Одеський національний університет імені I. I. Мечникова \\ м. Одеса, Украӥна
}

Мідії роду Mytilus є одними з найпоширеніших морських молюсків, що зустрічаються в прибережніх екосистемах обох півкуль [4]. На основі популяційно-генетичних методів дослідження було встановлено, що мідії Північної півкулі складаються з «видового комплексу Mytilus», до якого відносять три види: Mytilus galloprovincialis Lamarck, 1819, Mytilus edulis Linnaeus, 1758; Mytilus trossulus Gould, 1850 [7]. Особини цих видів, у зв'язку з високою генетичною подібністю, здатні схрещуватися між собою утворюючи гібридні зони в різних районах Світового океану [1].

Можливість точної ідентифікації видів та гібридів у «видовому комплексі Mytilus» має важливе значення для селективного управління запасами мідій та досліджень біорізноманіття [9].

Мідій Чорного моря за морфологічними характеристиками зазвичай відносять до виду M. galloprovincialis. Проте, серед особин мідій 128 
M. galloprovincialis в Чорному морі зустрічаються молюски, які за морфологічними особливостями мушлі не відрізняються від M. edulis i M. trossulus інших регіонів. Їх поява може бути результатом гібридизації інтродукованих видів M. edulis і M. trossulus з нативним видом M. galloprovincialis. На сьогоднішній день, генетичні підтвердження присутності $M$. trossulus, M. edulis i ïх гібридів з M. galloprovincialis в Чорному морі відсутні. Тому, цих молюсків розглядають, як trossulus-i edulis-подібні морфи [3]. У поселеннях мідій Одеського регіону більша частина молюсків (близько 60 \%) представлена galloprovincialis-подібними мідіями, а trossulus-подібних зустрічається менше $30 \%$ [2].

Мета роботи - встановити видову приналежність представників угрупувань мідій, що мешкають у північно-західній частині Чорного моря за допомогою молекулярного маркера $\mathrm{Me}$ 15-16 до неповторюваної області гена адгезивного білка мідії.

Матеріалом дослідження послужили 96 особин мідій, які були зібрані в різних районах північно-західної частини Чорного моря: в Одеській затоці (у локалізації А за географічними координатами $46^{\circ} 26^{\prime} 28^{\prime \prime}$ пн. ш., $30^{\circ} 46^{\prime} 20^{\prime \prime}$ сх. д.; у локалізації В $-46^{\circ} 22^{\prime} 2^{\prime \prime}$ пн. ш., $30^{\circ} 43^{\prime} 45^{\prime \prime}$ сх. д.; у локації Е - 46 $22^{\prime} 35^{\prime \prime}$ пн. ш., $30^{\circ} 45^{\prime} 7^{\prime \prime}$ сх. д.), в Сухому лимані (у локації D за географічними координатами - 46²0'22" пн. ш., $30^{\circ} 39^{\prime} 38^{\prime \prime}$ сх. д.) та біля острова Зміїний у локалізації $\mathrm{C}$ за

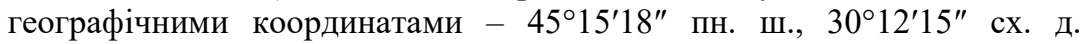
Геномну ДНК виділяли із ктенідій та мантії індивідуальних особин мідій за допомогою модифікованого методу з використанням СТАВ буферу згідно Saghai-Maroof et al. [8] та колонок фірми CONGEN Biotechnologie $\mathrm{GmbH}$ (Німеччина). Ідентифікацію угрупувань мідій проводили за допомогою ПЛР із застосуванням молекулярного маркера Me 15-16, який розташований в межах гена, що кодує поліфенольний адгезивний білок та відіграє важливу роль у прикріпленні мідії до субстрату [5]. Продукти ампліфікації ПЛР фракціонували у 7 \% поліакриламідному гелі (ПААГ) та фарбували азотнокислим сріблом відповідно до такої методики [6]. Розмір отриманих фрагментів ампліфікації визначали за допомогою програми GelAnalyzer (www.gelanalyzer.com) відносно маркеру молекулярної маси pUC 19 / Msp I.

За даними дослідження Inoue et al. [5], використовуючи молекулярний маркер Me 15-16, який розроблений, щоб контролювати поліморфізм за геном поліфенольного адгезивного білка, можна отримати три продукти ПЛР, що будуть відрізнятися довжиною 
фрагментів ампліфікації: 180 п.н. для M. edulis, 168 п.н. для M. trossulus i 126 п.н. для M. galloprovincialis.

За допомогою вказаного маркера Me 15-16 в нашій роботі було проаналізовано генетичний склад угрупувань мідій 3 п'яти локацій північно-західної частини Чорного моря: $з$ локації А було досліджено 28 особин, 3 локації В - 25 особин, 3 локації C -26 особин, 3 локації $\mathrm{D}-8$ особин, з локації $\mathrm{E}-9$ особин. Серед досліджених зразків особин мідій було детектовано лише фрагмент ампліфікації розміром 126 п.н.

Отже, досліджені локації $\epsilon$ мономорфними щодо алелю, який визначається фрагментом ампліфікації 126 п.н., і тому, складаються виключно з особин M. galloprovincialis. Отримані результати не підтверджують присутність двох морфологічно і генетично близьких видів (M. trossulus і M. edulis) та їх гібридів з M. galloprovincialis в досліджених локаціях Чорного моря.

\section{Література:}

1. Масалькова Н.А. Исследование молекулярной филогении мидий (Bivalvia, Mytilidae) дальневосточных морей России и особенностей дивергенции, генетической и морфологической изменчивости видов комплекса Mytilus ex. group edulis: автореф. дис. ... канд. биол. наук: 03.02.07. Владивосток, 2019. 128 с.

2. Стадніченко С.В. Морфологічні особливості trossulus-подібних мідій Чорного моря. Фауна Украӥни на межі XX-XXI cm. Стан $i$ біорізноманіття екосистем природоохоронних територій: матеріали міжнар. зоол. конф., присвяч. 220 річниці від дня народж. О. Завадського. (Львів - смт. Шацьк, 12-15 вересня 2019 р.). Львів: СПОЛОМ, 2019. С. 153-155.

3. Шурова Н.М. Структурно-функциональная организация популяций мидий Mytilus galloprovincialis Черного моря: монография. Киев: Наукова думка, 2013. 208 с.

4. Hilbish T.J., Mullinax A., Dolven S.I., Meyer A., Koehn R.K., Rawson P.D. Origin of the antitropical distribution pattern in marine mussels (Mytilus spp.): routes and timing of transequatorial migration. Marine Biology. 2000. Vol. 136. P. 69-77. DOI: 10.1007/s002270050010.

5. Inoue K., Waite J.H., Matsuoka M., Odo S., Harayama S. Interspecific variations in adhesive protein sequences of Mytilus edulis, M. galloprovincialis and M. trossulus. Biological Bulletin. 1995. Vol. 189. P. 370-375. DOI: 10.2307/1542155.

6. Promega Technical Manual. Gene Print. STR Systems. Printed in USA. Revised. 1999. Vol. 7. P. 52. 
7. Quack, M., Kosuch, J. Morphologische und genetische Untersuchungen an den Probenarten Miesmuschel (Mytilus edulis) und Blasentang (Fucus vesiculosus) unter besonderer Berücksichtigung von Hybridisierungseffekten. Trier: Universität Trier, Fachbereich VI Biogeographie, 2005. $170 \mathrm{c}$.

8. Saghai-Maroof M.A., Soliman K.M., Jorgensen R.A., Allard R.W. Ribosomal DNA sepacer-length polymorphism in barley: mendelian inheritance, chromosomal location, and population dynamics. Proc Natl Acad Sci. 1984. Vol. 81. P. 8014-8019.

9. Wilson J., Matejusova I., McIntosh R.E., Carboni S., Bekaert M. New diagnostic SNP molecular markers for the Mytilus species complex. PLOS ONE. 2018. № 13(7): e0200654. DOI: 10.1371/journal.pone.0200654. 